\title{
TAPPING INTO THE UNSUNG POTENTIAL OF TOURIST ATTRACTIONS FOR DEVELOPMENT IN SELECTED MUNICIPALITIES IN UGANDA
}

\author{
CHARLES TUSHABOMWE-KAZOOBA ${ }^{1}$, IMELDA KEMEZA ${ }^{1}$, MANASSEH TUMUHIMBISE ${ }^{1}$, \\ EDWARD ANDAMA ${ }^{2}$, RONALD EMOJONG ${ }^{2}$, ESTHER NANSAMBA $^{3} \&$ CHRISTINE AMPUMUZA $^{3}$ \\ ${ }^{1}$ Mbarara University of Science and Technology, Uganda \\ ${ }^{2}$ Busitema University, Uganda \\ ${ }^{3}$ Kabale University, Uganda
}

\begin{abstract}
The tourism sector (TS) in Uganda is predominantly nature based with potential to easily affect the fragile ecosystems. The sector is the top exchange earner, employs a significant proportion of the workforce, especially the unskilled, and contributes to the conservation of natural and cultural heritage sites. Therefore, if not managed properly, which must be preceded by documentation, the TS could lead to the destruction of the very resources upon which it depends. The concept of sustainability has often been used to indicate the need to ensure that tourism is developed in such a way that it minimizes the negative impacts. Inspired by the government's current drive to develop tourism cities, in this paper, we analyze the unsung/untouched paradise potential of tourist attractions (UPTA) in three purposively selected municipalities in Uganda. We use the concepts of attractions, activities and sustainability in a broader sense. The results are based on an extensive study of documents, unstructured interviews and observations. Our findings indicate that the three municipalities studied have a variety of UPTA that have potential to contribute to the social, economic, environmental and institutional essentials of sustainability. The UPTA also have a strong multiplier effect of creating jobs for marginalized groups and providing opportunities for designing inclusive institutions and policies. Such findings re-affirm that broadening the scope of sustainability and attractions beyond their physical references re-asserts the importance of UPTA amidst the current criticisms. This means increased livelihoods for not only the youth and women but also adults with high prospects to enhance household incomes. Furthermore, tapping into the UPTA contributes to revenue generation and foreign exchange earnings in the country.
\end{abstract}

Keywords: attractions, sustainability, unsung tourism, urban tourism, Uganda.

\section{INTRODUCTION}

Sustainable tourism is the fastest growing sector, dominates economic growth, creates jobs, promotes local culture and products, provides economic growth and shared prosperity world-wide [1]-[3]. Therefore, the expansion of tourism enables rapid economic and social development [4]. Moreover, the sector yields impressive results for the countries, which have been able to exploit their potential tourist attractions (PTA) [5]. The most prominent of these countries in Africa include South Africa, Egypt, Kenya and Tanzania, among others [6]-[8]. Such countries have invested immensely in their hotel industry, game parks, beaches and the transport sectors. Failure by other countries to tap into PTA due to several constraints has resulted in Africa's share of world tourism sector to remain small with the continents tourism growth rate standing at $1.5 \%$ in 2000. Despite that, World Tourism Organization's (WTO) long-term forecast for tourism is that international tourist arrivals will top one billion by 2010 and reach 1.56 billion by 2020 if tourist sites and supporting infrastructures in respective African countries are developed [9]. This unprecedented increase in tourist arrivals is an indicator of the importance of tourism to human wellbeing - the human/social dimension of the sustainability. These present great potential for tourism 
to act as a tool for development of both rural and urban places of underdeveloped countries like Uganda to spread tourism benefits to a wide spectrum of stakeholders.

As an example, Uganda has existing PTA that respond directly to growing trends in domestic, regional and international markets. Blessed with abundant rainfall and fabulous climate, the country has extraordinary natural beauty, and is rich in flora and fauna, many of which are unique. Uganda is ranked among the top ten countries in the world in terms of its bio-diversity. Besides, the country has more than 12 forests with large populations of primates in addition to being Africa's number one birding destination with 1056 officially sighted [10]. Various magazines have ranked Uganda as one of the six best places in the world for freshwater fishing [11]. Despite all these, Uganda remains relatively undiscovered as a tourism destination. Specifically, while tourism in the country has developed considerably overtime [12], [13], the municipalities on the other hand have not reaped so much from this profitable and fastest growing economic sector. Instead they have only remained as a stopover for tourists moving to other towns and districts in spite of having UPTA for development. To demonstrate the growth of tourist attractions in the country for example, from 1983 to 2003 , the number of tourists increased from 12,786 to 305,720 , an increase of $2,291 \%$ over 20 years. In 2004, tourist arrivals short to 512,379, an increase of $68 \%$ over the previous year [14].

Furthermore, although tourism in major cities of the world is as old as tourism itself, with the increasing number of tourists each year, various countries are focusing on tourism as a tool for developing their cities. Following this trend, Uganda has already named the municipalities of Kabale and Fort portal among others as tourism cities. The role of municipalities in promoting tourism cannot be over emphasized [15]. However, recent studies indicate that if not handled well, cities might face the over tourism crisis [16]. Such crises may even lead to the downfall of the very city which was envisaged to benefit from tourism [17]. Accordingly, this is the gap the authors of this paper are addressing.

Hence, the above area of debate gives rise to the following research guiding objectives:

(i) To document ecologically-sound UPTA from the three selected municipalities in Uganda

(ii) To establish sustainable revenue-generation tourism types through UPTA for

(ii) sustainable tourism management and for community development in areas surrounding the municipalities

(iii) To link UPTA in selected municipalities to the national and regional context for enhanced practical collaboration on conservation management between municipalities and the protected area authorities in adjacent parks and tourism potentials in the country.

(iv) To suggest ways of tapping the UPTA in the three selected municipalities in Uganda.

Furthermore, a number of PTA are part of the seven wonders - Gorilla Trekking, Kazinga Channel, Murchison Falls National Park, Rwenzori Mountains, Kibale Forest National Park, Lake Victoria and Mount Elgon are located in tourism distribution hubs. As such Mbale, Jinja, Kisoro, Ssese Islands and local governments have endeavored to develop the attractions. Accordingly, the districts and communities are able to reap from the flourishing TS and consequently support their development. On the contrary, municipalities 
have modestly exploited into tapping their UPTA, consequently losing out continuously. It is against this background that this study was undertaken to establish the different UPTA for development. What is most important as well as is to suggest ways of marketing the municipalities as major tourists' circuits. Consequently there will be a multiplier effect in the development in terms of addressing the ever increasing unemployment especially youth at $83 \%$, the static employment in the formal sector outside agriculture averaging $15.1 \%$ [18], food insecurity, limited technology uptake, the rapid and extensive rural-urban transition and, disease burden, climate change, gender inequality and inequity [19] among the other challenges of implementing the Sustainable Development Goals (SDGs) in Uganda [20], [21].

The authors of this paper are from three universities. Therefore, in order for universities to continuously provide quality, relevant education and its application to community development, zeroing on the sector is the ideal thing to do. For this reason, the universities agree that tourism and hospitality sector remains the top exchange earner at nearly US\$1.6 (about 6 trillion annual). This is almost 23\% of Uganda's export earnings. It brings foreign exchange for the development of the economy. Also the sector contributes $9 \%$ of the Gross Domestic Product (GDP) and employs 8\% of Uganda's workforce. The increasing tourist arrivals into Uganda have been increasing by $21.7 \%$ from 2010 and currently are at $1,151,000$ visitors [22]. Most important, we point out that this paper prioritizes the private sector particularly the informal business of the sector.

Therefore, given the development potentials of tourism and the likely negative impacts on cities, this paper aims at documenting the UPTA in three Ugandan municipalities: Mbarara, Kabale located in South Western Uganda and Tororo in Eastern Uganda, and recommends measures to sustainably develop these municipalities by minimizing the negative impacts. In the next section we will provide an overview of tourism in the country before providing the conceptual framework, methods and a discussion of the results of our study.

\section{LITERATURE REVIEW}

Tourism in Uganda began in earnest in the 1950s with the gazetting of Queen Elizabeth National Park, Murchison Falls National Park, Kidepo National Park and other protected area system such as the gazettment of Bwindi Impenetrable Forest (BIF) in October, 1991. The principal attractions were the superabundance of animals and the incredible diversity of scenery. By the 1970s, there were hundreds of thousands of holidaymakers flooding into Uganda and the country was an integral part of the then famous East African Circuit, which also covered Kenya and Tanzania. During the 1960s tourism was the third largest foreign exchange earner for the country, after the traditional cash crops of cotton and coffee, grossing up to US\$19 million in 1970 [23]. The sector as with other sectors of the economy, however, suffered tremendously from the years of political turmoil in the period 1970 to 1986. This period saw a major deterioration in the services offered by hotels, neglect of game parks and reserves in addition to the incessant political turmoil, a deterrent to tourism [24].

We point out that Uganda is endowed with plentiful natural and cultural resources. These resources form the basis for a very lucrative tourism industry, create employment and generate income not only to the dwellers in the major economic centers but also in rural areas. Furthermore, through tapping unsung tourism potentials, the country will be better able to protect its rich biodiversity and cultural heritage [25]. A complex amalgam of morphology, climate, fauna and flora make the country one of the popular tourist attractions in the world since the sector is nature based [26], [27]. Additionally, the country boasts of 
numerous volcanic mountains such as Moroto and Elgon in the East, and Muhavura, Virunga and Visoke in the Southwest. Volcanicity which occurred during the Plio-Pleistocene period is also responsible for over 200 crater lakes in Western Uganda. Many of the crater lakes contain water from Mount Ruwenzori rising to a height of 5,125 m above sea level is the highest point in Uganda and the third highest mountain in East Africa. It has 37 glaciers which are remnants of the Plio-Pleistocene glaciation. Just like above, attractions in Uganda are pointed out including those in western Uganda, but still, the country has unsung attractions which need to be exploited.

The sunny climate of the country is complementary. It has to be emphasized that the elevation moderates the temperatures despite the fact that Uganda lies astride the Equator. The cool temperatures of Kigezi Region have made Uganda to be referred to as "the Switzerland of Africa". Truly, the warm climate is just one of the unexploited attractions in the country. This is one such ignored potential to develop like sunbathing. This therefore indicates a gap that requires an investigation.

Studies indicate that Uganda is second to Australia and has over 107 species of snakes of the 2,700 in the world. Furthermore, there are over 1,010 species of birds [28]. As an example, Queen Elizabeth National Park alone has over 550 species which is an African park record. While these statistics are quite interesting, little is documented about bird watching considered as unsung tourists' attraction as an activity in the selected municipalities. If tapped, however, as a way of urban tourism, it will also be a way of conserving birds. Another great advantage of Uganda as a tourism center is the presence of mountain gorillas in Mgahinga Gorilla National Park and Bwindi Impenetrable National Park. These include many natural equatorial forest reserves such as Kibale, Mabira, Budongo and Maramagambo as well as montane forests on Ruwenzori, Elgon and the Virunga mountains. In many isolated places, there exist giant trees like the Nakayima tree in Mubende. It is 350 years old, $40 \mathrm{~m}$ tall with 15 buttresses dividing the base into separate bays or transepts [29].

Sports facilities are also available in the country. Golf players can enjoy themselves at the vast Kampala Golf Course and Lugogo indoor stadium (for indoor games) in Kampala City. Tourists are able to return to their countries of origin with crafts like mats, baskets, drums, bags, pillows and bed covers from cattle hides. These are sold in many outlets such as souvenir and craft shops located in hotels, Entebbe International Airport and along the roads. The peace prevailing in most parts of the country enables the availability of a flourishing and entertaining night life [30]. The selected municipalities have sports facilities which need to be tapped, a gap which this study intended to bridge.

The launching of the Tourism Master Plan (TMP) during the same year and the relative peace and stability, have combined to attract investors into the country. The government also awarded a number of concessions for developing accommodation facilities for tourists in the national parks. As a result, an additional 1,052 new beds of international standards were added by the end of 1995. A significant change that has taken place in the tourism sector is gorilla viewing. It is now the greatest tourist attraction in the country when Bwindi Impenetrable National Park (BINP) was declared a National Park (NP) in 1991 and started gorilla trekking on April 1, 1993. As an example in 1994, 2,476 tourists visited the park [31], [32]. The highlighted general development plans being pursued by the government is not clear how to tap the unsung potential attractions to develop in the municipalities.

Finally, tourism as an industry has many components, an undeveloped and narrow product range, involves inadequate and unskilled manpower/personnel. Along with transportation, it includes such products as accommodations, food and beverages services, shops, entertainment, aesthetics and special events. Therefore, it is rare for one business to 
provide the variety of activities or facilities tourists need or desire. This adds to the difficulty of maintaining and controlling the quantity and quality of the experience. Thus, to overcome this hurdle, relevant stakeholders involved in the sector related businesses, agencies, and organizations need to work together to package and promote tourism opportunities in their areas and align their efforts to assure consistency in the overall product quantity and quality [33]. Some of these related businesses are untapped.

With the above literature search, we have also established the key words that were being used in connection with tourism. These appeared to fall into five categories. With slight modifications, the groups are natural attractions (NA), recreation and sports facilities attractions (RSF), religious attractions (RA), historical attractions (HA) and hospitality, hospital, University and factories (HHUF) attractions. The same was done with the tourism type. Our examination revealed 18 tourism types: adventure tourism (AT), business tourism (BT), cultural and heritage tourism (ChT), community tourism (CT), cultural trail tourism (CTT), eco-tourism (EcT), faith tourism (FT), mountain climbing tourism (McT), medical tourism (MeT), medicinal tourism (MT), missions and volunteer tourism (MVT), nature-based tourism (NT), regional tourism (ReT), rural tourism (RT), sports tourism (ST), traditional dress code (TDC), township tourism (TT) and wine tourism (WT). We use these abbreviations to represent the tourism categories and the tourism types/activities respectively in the subsequent sections of this paper.

\section{CONCEPTUAL FRAMEWORK}

In 1972, Clare A. Gunn, as cited by Lew [34], asserted that, "without attractions, there would be no tourism". Also makes the point that without tourism there are no attractions and goes on to summarize the importance of attractions in tourism. Therefore, attraction is our major concept in exploring the UPTA in light of the sustainable tourism debates.

\subsection{Attractions}

But as Lew [34] states, PTA have been conceptualized in various ways - as exploitable resources, marketable products, and image among others. Current research on PTA advocates for a shift from traditional attractions to Smart Tourism Attractions (STA) by embracing smart technologies that accurately link tourist preferences and destination attributes [35]. Despite the various conceptualizations, our understanding is that there is a seeming consensus that an attraction draws/evokes interest, desire to see, hear, use and feel among others. In our view, this implies that an attraction transcends the tangible (physical) aspects to include the intangible (psychological, spiritual, intellectual and emotional) domains. Once drawn by an attraction, people do a variety of things thus, our second concept of tourism activities/types.

\subsection{Activities}

Activities refer to the range of things that a tourist does at a place, event, and people/community to which they are drawn. In some cases, activities reflect the interest of tourists and have been used in developing tourist and tourism typologies. For example, ecotourism scholars use activities to differentiate ecotourism from mass tourism. They emphasize that activities have to be small-scale, locally owned, ecologically sensitive and provide learning opportunities [36]. Therefore, activities are at the core of the tourist experience. Campos et al. [37], on the other hand observe that tourism has shifted from mere gazing to active physical, mental and emotional interaction with the nature, other 
tourists, residents and technologies. Therefore, our analysis considers how the UPTA provide opportunities for such interactions. Most importantly, is that in our analysis we also reflect on how the tourist experience equally creates meaningful experiential moments for the residents, and staff/employees. So far, it is clear that this conceptualization of attractions and activities highlights important linkages with the main tenets of sustainability. Therefore, we explore this concept in detail.

\subsection{Sustainability}

The generic sustainability model focuses on balancing the economic, environmental and social imperatives taking into consideration the future generations [38]. Important for our study, Chapter 9 of the Brundtland report highlighted the urban challenge for developing countries as increased industrial pollution, population, inadequate poor sanitation facilities, and most importantly underdeveloped land/resources. As a result, one of the recommendations was urban agriculture and promotion of public-private cooperation to utilize these resources. As if to emphasize the recommendation for cooperation, Valentin and Spangenberg [39] adds the institutional imperative that focuses on the mechanisms and processes of inclusive participation in the development process.

Moreover, Deery et al. [40] add that sustainable tourism should also consider the wellbeing of the employees. The recurrence of these issues in the Sustainable Development Goals (SDG) and the relative ability of tourism to contribute to all these imperatives despite the negative impacts of tourism [41] indicates that sustainable tourism debates are still as pertinent today as they were in the 1980s. Based on that importance, our analysis of UPTA explores the tangible and intangible attractions in terms of the possibilities they offer for holistic experiences for the tourists, residents and staff, and how these contribute to the social, economic, environmental and policy/institutional imperatives of sustainability (Fig. 1).

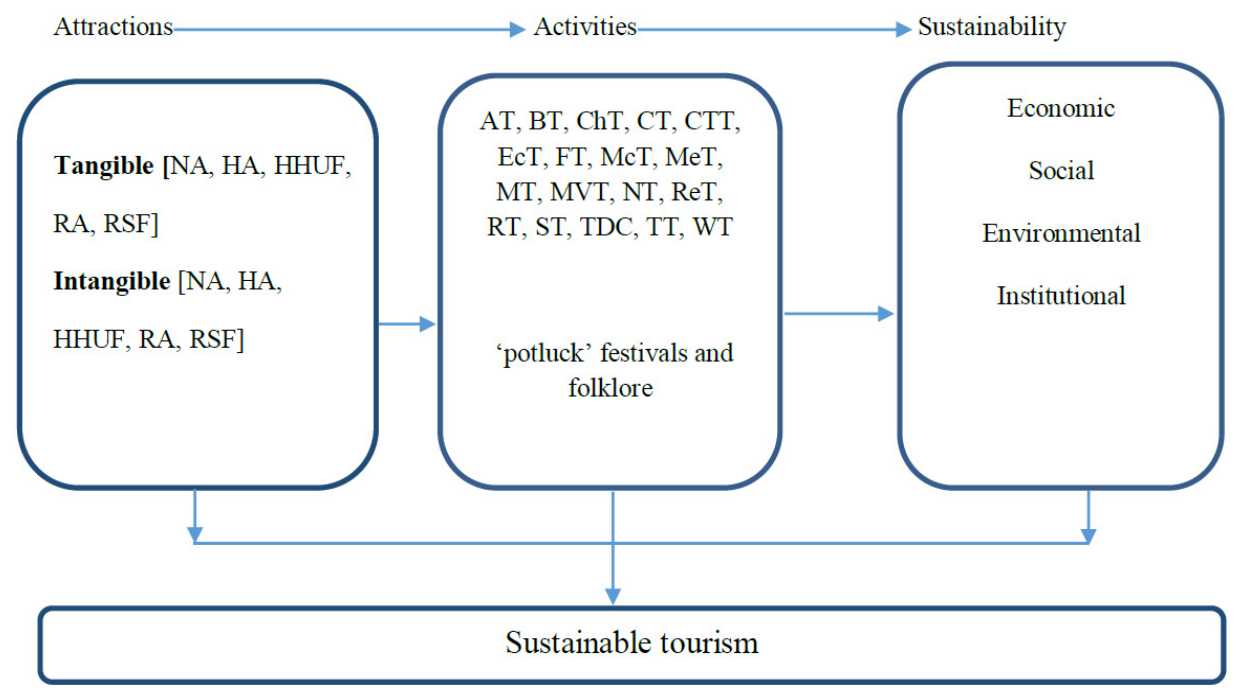

Figure 1: Conceptual framework for analyzing UPTA. 


\section{METHODOLOGY}

The three selected municipalities have unique UPTA. They boast of a fastest growing commercial center with a growing population, leisure, religious and education centers. The study was conducted from September 2019 to March 2020. Ethically, this study posed minimal risk to those who were involved. It was based on generally available information, documents, publications, archival materials and through inventory and in-depth interviews. Each interview was individually tailored to draw out information from which interviewees could freely express their ideas [42] and make comments regarding UPTA of the urban settings and the surrounding areas/communities. Purposive sampling and simple random sampling were used to identify respondents in the data collection process (Table 1).

Table 1: Study participants from the selected municipalities in Uganda.

\begin{tabular}{|c|c|c|c|c|c|}
\hline Name & Gender & Position; number & Qualifications & $\begin{array}{l}\text { Years of } \\
\text { experience }\end{array}$ & $\begin{array}{c}\text { Data } \\
\text { collection } \\
\text { tools; } \\
\text { sampling } \\
\text { procedures }\end{array}$ \\
\hline $\begin{array}{l}\text { Eastern Uganda } \\
\text { BU } \\
\text { Tourism clusters }\end{array}$ & $\mathrm{M} / \mathrm{F}$ & TS; 4 & TESTS & Various & IS; P \\
\hline $\begin{array}{l}\text { Busoga tourism } \\
\text { network }\end{array}$ & $\mathrm{M} / \mathrm{F}$ & Members; 5 & IB & Various & IS; P \\
\hline $\begin{array}{l}\text { Eastern } \\
\text { entrepreneurship and } \\
\text { tourism }\end{array}$ & $\mathrm{M} / \mathrm{F}$ & Members; 4 & IB & Various & IS; P \\
\hline Tourism associations & $\mathrm{M} / \mathrm{F}$ & Members; 6 & IB & Various & IS; P \\
\hline $\begin{array}{l}\text { Hotel owners and } \\
\text { hospitality }\end{array}$ & $\mathrm{M} / \mathrm{F}$ & $\begin{array}{l}\text { Owner and } \\
\text { Manager; } 3\end{array}$ & IB & Various & IS; P \\
\hline Crafts associations & $\mathrm{M} / \mathrm{F}$ & Members; 7 & IB & Various & IS; SR \\
\hline Local governments & $\mathrm{M} / \mathrm{F}$ & Various; 3 & LGSs & Various & IS; P \\
\hline $\begin{array}{l}\text { Tour operators } \\
\text { Southwestern Uganda }\end{array}$ & $\mathrm{M} / \mathrm{F}$ & Owners; 2 & IB & Various & IS; SR \\
\hline MUST & $\mathrm{M} / \mathrm{F}$ & $\mathrm{TS} ; 3$ & TESTS & Various & IS; P \\
\hline KAB & $\mathrm{M} / \mathrm{F}$ & TS; 4 & TESTS & Various & IS; P \\
\hline $\begin{array}{l}\text { Local governments } \\
\text { Tourism clusters }\end{array}$ & $\mathrm{M} / \mathrm{F}$ & Various; 3 & LGSs & Various & IS; P \\
\hline Kigezi & $\mathrm{M} / \mathrm{F}$ & Members; 5 & IB & Various & IS; P \\
\hline Gantone & $\mathrm{M} / \mathrm{F}$ & Members; 4 & IB & Various & IS; P \\
\hline $\begin{array}{l}\text { Hotel owners and } \\
\text { hospitality }\end{array}$ & $\mathrm{M} / \mathrm{F}$ & $\begin{array}{l}\text { Owner and } \\
\text { Manager; } 3\end{array}$ & IB & Various & IS; P \\
\hline Tourism associations & $\mathrm{M} / \mathrm{F}$ & Members; 2 & IB & Various & IS; P \\
\hline Crafts associations & $\mathrm{M} / \mathrm{F}$ & Members; 5 & IB & Various & IS; SR \\
\hline Training institutions & $\mathrm{M} / \mathrm{F}$ & TS; 3 & TESTS & Various & IS; P \\
\hline Cultural institutions & $\mathrm{M} / \mathrm{F}$ & Delegated; 2 & IB & Various & IS; P \\
\hline Religious institutions & $\mathrm{M} / \mathrm{F}$ & Leaders; 3 & IB & Various & IS; P \\
\hline
\end{tabular}

We used in-depth semi-structured qualitative interviews for data collected which was conducted among 71 study participants (KM - 19(26.7\%); MM - 18(25.4\%) and $\mathrm{TM}-34(47.9 \%))$ as "representative characterization" [43] to gain information on unsung tourism potential in the selected municipalities focusing on the urban tourism development and also to explore the weaknesses and strengths of local authorities in terms of their participation in the tourism planning process in the urban setting.

Additionally, observation method was used and this refers to an extremely wide range of processes carried out, both in a selective, specific, systemic component, and especially at the level of interaction relationships with the target items and recording the information 
systematically. The semi-structured interviews were recorded and analyzed with the framework techniques. All recordings of the interviews were transcribed verbatim and categorized into keywords, followed by indexing, coding, and classifying by themes and categorization of the data into themes was conducted repeatedly and frequently during the analysis phase.

Both primary and secondary data was collected. This qualitative study is based on a study of various documents such as district and municipal tourism plans, the Kigezi Tourism Cluster Platform baseline survey report on tourism in the region, Uganda Tourism Master plan 2015, Uganda National Development Plan II and III and Uganda's Vision 2040, Ministerial policy statements of the Ministry of Tourism Wildlife and Antiquities (MTWA) and Uganda Wildlife Authority (UWA) policy documents.

Furthermore, 71 unstructured interviews were conducted with the Commissioner Department of Antiquities and Museums under the MTWA, municipality Planners, Commercial Officers, Environmental Officers, selected LC1 chairpersons, Tour and travel operators, owners, Managers/Caretakers of potential attractions, tourists and excursionists found at such attractions located in MM, KM and TM. The documents and unstructured interviews provided insights into the UPTA. This data was augmented by observations aided by field visits to the sites conducted between the months of October 2019 and March 2020.

The potential sites were analyzed using the framework provided in the next section. Data was analyzed and interpreted using both qualitative and quantitative techniques of analysis.

\section{PRESENTATION, ANALYSIS AND DISCUSSION OF STUDY FINDINGS}

This study sought to document ecologically-sound UPTA and facilities that could be developed into tourist activities (Fig. 2).

We present in Table 2 the key UPTA categories and the tourism types.
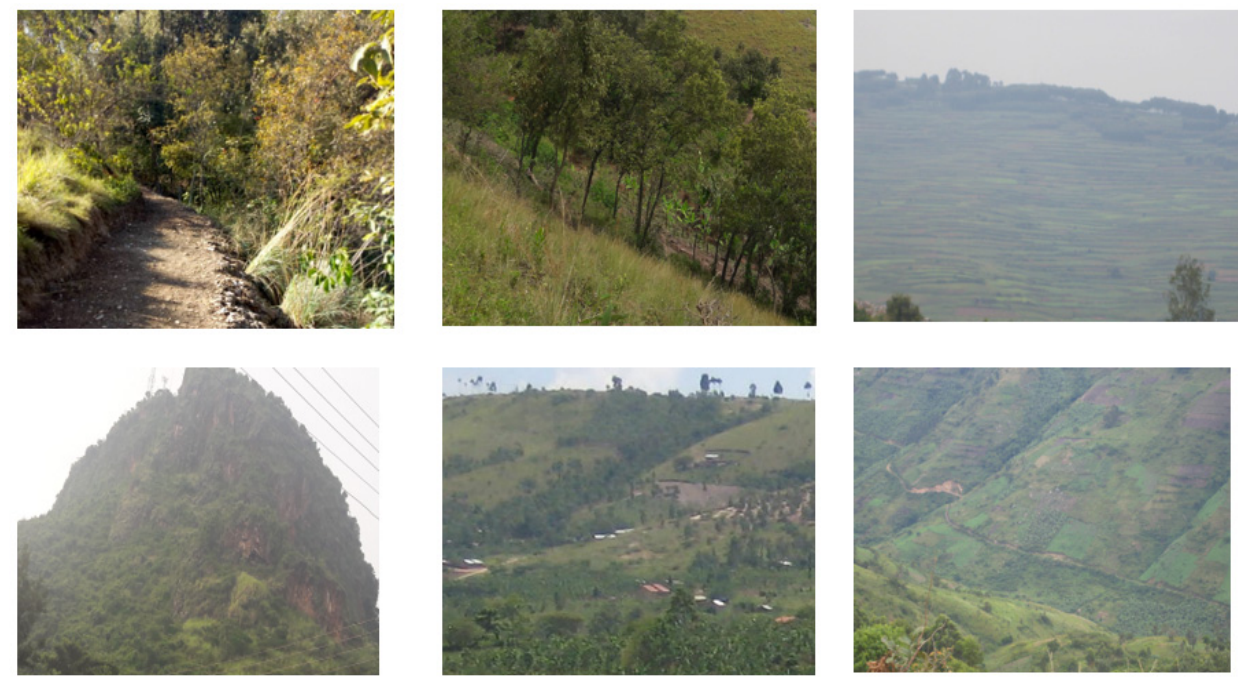

Figure 2: Examples of UPTA in selected municipalities in Uganda. 
Table 2: Category of UPTA, examples and tourism type in the selected municipalities in Uganda.

\begin{tabular}{|c|c|c|}
\hline $\begin{array}{l}\text { Category of } \\
\text { UPTA }\end{array}$ & Key examples & Tourism type \\
\hline \multicolumn{3}{|c|}{ Mbarara Municipality, Southwestern Uganda } \\
\hline NA & $\begin{array}{l}\text { River Rwizi and its associated waterfalls and beautiful sceneries, Round } \\
\text { topped Hills, traditional trees, medicinal plants, indigenous flora and fauna } \\
\text { species, various bird species }\end{array}$ & $\begin{array}{l}\text { EcT, AT, CT, } \\
\text { McT, MT, } \\
\text { NbT, RT }\end{array}$ \\
\hline RSF & Kakyeka Stadium, Booma Golf Course, numerous hotels & $\mathrm{ST}, \mathrm{CT}$ \\
\hline HHUF & $\begin{array}{l}\text { Mbarara Regional Referral Hospital (MRRH), informal wine processing, } \\
\text { MUST, Nile Breweries, hotels }\end{array}$ & $\begin{array}{l}\text { BT, MeT, } \\
\text { MeT, MVT, } \\
\text { WT }\end{array}$ \\
\hline RA & $\begin{array}{l}\text { Churches, Hindu temple, mosques, East Africa Revival Museum, } \\
\text { Amahembe Gente, Burial Place for former colonial administrators, Old House }\end{array}$ & $\begin{array}{l}\text { FT, MVT, } \\
\text { EcT, ChT, }\end{array}$ \\
\hline HA & $\begin{array}{l}\text { Burial Site of the former Kings of Ankole, eclipse hill, traditional huts, } \\
\text { cultural tours }\end{array}$ & $\begin{array}{l}\text { TDC, } \operatorname{ReT} \text {, } \\
\text { TDC, TT }\end{array}$ \\
\hline \multicolumn{3}{|c|}{ Kabale Municipality, Southwestern Uganda } \\
\hline NA & Hills, cultivation terraces, meandering roads, nuclei settlements systems & $\begin{array}{l}\mathrm{AT}, \mathrm{McT} \\
\mathrm{NbT}, \mathrm{RT}\end{array}$ \\
\hline RSF & Golf grounds, Kabale Stadium, numerous packaged hotels & ST, CT \\
\hline HHUF & $\begin{array}{l}\text { Kabale Regional Referral Hospital (KRRH), numerous hotels, informal wine } \\
\text { processing, KAB, hotels }\end{array}$ & $\begin{array}{l}\text { BT, MeT, } \\
\text { MVT, WT }\end{array}$ \\
\hline RA & Church and mosque buildings, & $\begin{array}{l}\text { FT, MVT } \\
\text { ChT, CT, }\end{array}$ \\
\hline HA & Cultural Institutional infrastructures & $\begin{array}{l}\text { CTT, ReT, } \\
\text { TDC, TT }\end{array}$ \\
\hline \multicolumn{3}{|c|}{ Tororo Municipality, Eastern Uganda } \\
\hline NA & $\begin{array}{l}\text { Tororo Rock (TR), volcanic plug, Indigenous plant species, various bird } \\
\text { species, caves, Usukuru hills, cable car, Busitema forest, nuclei settlement } \\
\text { systems }\end{array}$ & $\begin{array}{l}\text { AT, EcT, AT, } \\
\text { CT McT, MT, } \\
\text { NbT, RT }\end{array}$ \\
\hline RSF & Golf Course & $\mathrm{ST}, \mathrm{CT}$ \\
\hline HHUF & $\begin{array}{l}\text { BU, cement factories - Tororo Cement industries ltd, Simba Cement and } \\
\text { Hima cement, inland port, Tilda Kibimba rice Scheme }\end{array}$ & $\begin{array}{l}\text { BT, MVT, } \\
\text { CT }\end{array}$ \\
\hline RA & Church and mosque buildings & FT, MVT \\
\hline HA & Adhola cultural Institution (ACI), the Bayole, the Etesot and the Bagisu & $\begin{array}{l}\text { ChT, CTT, } \\
\text { TDC, TT }\end{array}$ \\
\hline
\end{tabular}

Source: Field research, September 2019 to March 2020.

\subsection{The UPTA in MM}

As indicated in Table 3, this study established that "Ebituro bya Abagabe site" is one of the potential attraction that can be developed to attract tourists and recreationists to stay longer in the MM. Located in Nkokonjeru in Kamukuzi Division, this study discovered that although the site which is currently under the Department of Museums and Monuments (DMM) houses prominent former kings of Ankole Kingdom, it is in a sorry state. We indicate that if this site is well-developed, it could attract tourists to the municipality. We suggest the development of cultural trail to link all important cultural attractions in the municipality.

According to the Commissioner of DMM-MTWA, MM has several cultural sites that can be developed by linking them in a trail which provides connectivity of activities to create meaning and experience worth selling to tourists. Such cultural sites include the burial site of the traditional kings of Ankole, the Headquarters of the Abagabe at Kamukuzi, Kiyanja Lake, River Rwizi, indigenous trees and shrubs in the hills of Biharwe division among others all of which could be developed into PTA. This study further indicates that once a cultural trail is developed, cultural and gift shops could also be 
developed alongside so as to provide an avenue for tourist shops most especially those interested in traditional shoes, necklaces, and drums among others. Besides that, traditional dance could be developed to entertain tourists. We noted that Igongo Cultural Centre is still in its infancy stage in this tourist product. All this could provide alternative activities for tourists and a reason to stay longer than bypassing MM.

The presence of River Rwizi with its magnificent meandering and other features provides an option for boat riding and canoe loving tourists to enjoy scenic viewing, natural plant identification and bird watching among others. Most of the river sections are navigable. This would provide more fun and experience for tourists besides already existing UPTA in the municipality. If the tourist market segment of MVT is developed, the municipality could be a safe landing haven for such.

$\mathrm{CT}$ activity was also identified as worth developing. With a shift in tourist interests from mere wildlife safaris to responsible, cultural and community tours, the municipality can position herself very well. To benefit from community tourists should be welcomed in homes of Ugandans so as to participate in the day today routine of the local people for an in-depth experience and understanding of lives of Ugandans. This would not only be exciting but would be a worthwhile activity to occupy the tourists, which means more expenditure.

\subsection{The Lake Ngorogoza and its UPTA in KM}

In KM, we use the example of Lake Ngorogoza to demonstrate how the municipalities can tap into UPTA (Table 3).

Table 3: Tapping into UPTA for development: The Lake Ngorogoza Case, KM.

\begin{tabular}{|c|c|c|}
\hline Description and location & $\begin{array}{c}\text { Tourism } \\
\text { type }\end{array}$ & $\begin{array}{c}\text { Contribution to sustainability } \\
\text { imperatives }\end{array}$ \\
\hline $\begin{array}{l}\text { Ngorogoza Lake: This is a man-made pond } \\
\text { surrounded by a lush swamp - a habitat for pretty } \\
\text { birds such as the hammerkop, sacred ibis, pied } \\
\text { kingfisher, malachite kingfisher, black headed, } \\
\text { yellow backed and red chested weavers among } \\
\text { others. This is in addition to invertebrate and plant } \\
\text { diversity undoubtedly important providing a } \\
\text { greenery in a predominantly constructed area. The } \\
\text { lake named after the famous leader of Kigezi } \\
\text { Region who, in spite of lack of formal education } \\
\text { was very instrumental in the history of Kigezi as the } \\
\text { first general secretary appointed by the colonial } \\
\text { administration. }\end{array}$ & $\begin{array}{c}\text { EcT, AT, } \\
\text { CT, McT, } \\
\text { MT, NbT, } \\
\text { RT }\end{array}$ & $\begin{array}{l}\text { Environmental }- \text { Protection of the } \\
\text { biodiversity and all associated benefits } \\
\text { to people's health. } \\
\text { Social - Revitalization of historical and } \\
\text { cultural heritage } \\
\text { - Fostering community pride in their } \\
\text { heritage } \\
\text { Provides learning opportunities for } \\
\text { the tourists on nature, culture and } \\
\text { history of Kigezi } \\
\text { Enriched tourist, employee and } \\
\text { residents experience through } \\
\text { learning activities } \\
\text { Economic - revenue from tourist } \\
\text { payments for the activities to the } \\
\text { owners, taxes to municipal authorities. } \\
\text { Policy/institutional - offers an } \\
\text { opportunity for various institutional } \\
\text { arrangements e.g. Private Community } \\
\text { Partnerships or Public - Private } \\
\text { Partnerships (PPP). } \\
\text { - Can act as a focal point for other } \\
\text { community activities by taking } \\
\text { into account the activities of other } \\
\text { residents around the lake leading } \\
\text { to a joint e.g. Mwanjari Tourist } \\
\text { Destination Management Team. }\end{array}$ \\
\hline
\end{tabular}




\subsection{The Tororo Rock and its UPTA in TM}

In TM, there is the Tororo Rock (TR). The geographical coordinates of the rock are: $004106 \mathrm{~N}, 341101 \mathrm{E}$ (Latitude: 0.6850; Longitude: 34.1836 ). The rock is generally visible from anywhere in the Tororo District (TD). Thus, it is a major tourist attraction for the district. There is a saying in Tororo that: "The Eiffel Tower is to Paris as the magnificent TR is to TD". The highest altitude of the rock is $4,865 \mathrm{ft}(1,483 \mathrm{~m})$ with a gradient of about 0.75 from the east to the west. On the rock's slopes are ancestral caves and various rock paintings. The elevation of Tororo Town is $3,888 \mathrm{ft}(1,185 \mathrm{~m})$. Therefore, TR towers $977 \mathrm{ft}$ $(298 \mathrm{~m})$ above downtown. Furthermore, the TR is a volcanic plug or a volcanic neck or lava neck, which is a volcanic landform created when magma hardens within a vent on an active volcano. The plug is preserved after the erosion removes the surrounding rock while the erosion-resistant plug remains, producing a distinctive upstanding landform the rock.

This study indicates that the UPTA of TR are many. As an example, the rock has caves some of which act as shrines, home for bats, snakes, and other reptiles. We observed that the rock is an important bat sanctuary in the district. It also has indigenous plants as well as wild mammals such as monkeys, rabbits, birds, porcupines, small antelopes which are all rarely found in other parts of TD due to the degraded natural habitats. Recently Aloe tororoana plant which is restricted in occurrence was confirmed to be only found in the two locations (i.e. TR and Usukuru Hills) in TD in the whole of Uganda and perhaps the world. This creates the urgency to conserve the plant as it might disappear from the earth's surface. Andama and Alezuwo [44] indicates that TR is perhaps the only remaining site in the district with more natural or indigenous vegetation. Some of the indigenous plant species still grow intact on the rock while most natural vegetation in other parts of the district has disappeared due to intensive farming and increased human settlement.

\subsection{Suggested key strategies for promotion of UPTA}

From the empirical evidence of this study, the following are the key strategies for promotion of UPTA in the selected municipalities in Uganda. Some of these strategies are:

1. In TM, promote rock hiking along the trails and rock climbing to the top of the rock. This can be an annual event for the site to be widely advertised.

2. Both MM and TM, tap into viewing the indigenous trees and bird species.

3. In all the municipalities, promote visits by various academic institutions for study

3. purposes, namely, biology, ecology, geography and chemistry.

4. All the municipalities, promote the documented UPTA sites for research activities on ecology and natural resources management in urban setting.

5. In all municipalities, local artisan materials be promoted at the center as commercial business for tourism and local CT.

6. Annual cultural gala during which various cultural groups in the municipality to

6. express their cultural wealth, commonality, such as poetry, song, dance, festivals and forms of art as this promotes UPTA in the country. 
6 CONCLUSIONS, RECOMMENDATIONS AND POLICY IMPLICATIONS

This section advances the conclusions, recommendations and policy implications derived from the study findings. The section starts by pointing out the conclusions from the study findings. The section later points to the recommendations and directions for further research, and policy implications that were advanced by the study based on empirical evidence provided by the study findings on tapping UPTA to develop in the selected municipalities.

The findings reveal that despite the fact that the selected municipalities are still unable to compete with most tourist sites and destinations within the country for both international and domestic tourists, they are in position to provide most outdoor recreation and urban tourist attractions once all the potential attractions identified by the study are well developed. We categorized the UPTA in 5 categories especially the intangible ones. Majority of the UPTA observed were found to be in a very sorry state, an indication that there are either no policies or plans to protect, conserve and develop such attractions. There is absence of a Tourism Officer at both Municipalities and District level an indication of disinterest by the district in as far as tourism development is concerned. Moreover, all the three municipalities had no useable developed website. Additionally, the study established that alongside an overlap of tourism types, there is also municipality specific tourism types which once developed could reckon with sustainable revenue generation. Also, UPTA in selected municipalities links to the national and regional context through SDG, Goal 5 on the planned inclusion of marginalized groups and on one of the 8 AU/NEPAD objectives in Tourism Sector, objective 4.

\subsection{Recommendations and directions for further research}

In this article, we offer several recommendations for tapping into UPTA for development in the selected municipalities in Uganda. Firstly, there is need for the local governments to establish a tourism office/department staffed with qualified tourism officers to document an inventory of UPTA in consultations with other stakeholders involved in the tourism value chain. We suggest that a Municipality Tourism Development Plan (MTDP) should be designed to guide tourism development. Once the MTDP is in place, it will guide all stakeholders on what and how to develop the UPTA. A leaf should be borrowed from Districts in the country which have Tourism Plans that it is a strong driving tool towards the development of the sector. While the Ministry of Tourism, Wildlife and Antiquities (MTWA) is made up of Departments, namely, Tourism Development, Wildlife Conservation, Museum and Monuments, this study indicates there is minimal working with Municipalities to attract private investors to develop the untouchable paradise into viable activities capable of attracting tourists. Besides that, capital to invest in developing these attractions can be mobilized through public-private partnership (P3) with MTWA playing a leading role.

This study calls for proper management and conservation of most UPTA. We point out that a lot of degradation along the banks of river Rwizi in MM, Tororo Rock and Busitema Forest in TM, and Ngorogoza Lake in KM was observed where natural vegetation is being cleared away for the sake of growing crops. The forest and natural vegetation act as home for bird species popular for bird watching activity. We suggest that the District Environmental Officers (DEOs) in conjunction with other stakeholders should ensure the conservation of these natural greens.

On a critical note, there is need for extensive marketing, while focusing and incorporating urban authorities in order to exploit the incredible UPTA in Uganda to be 
known worldwide. Major players in the country's tourism sector such as the Uganda wildlife Education Center (UWEC), Uganda wildlife Authority (UWA), Export Promotion Board (EPB), Uganda Tourism Board (UTB), Uganda Wildlife Research and Training Institute (UWRTI), Uganda Hotel and Tourism Training Institute (UHTTI) and the Civil Aviation Authority (CAA) among others should work together with urban authorities to promote worldwide awareness about UPTA products in the country. Joint marketing and promotion of UPTA products is highly encouraged.

Moreover, there is need to devote more resources to the marketing and promotion of tourism particularly on the international front where per-capita income is the greatest. Severe loss of market share, tourist foreign exchange and tax revenues has been realized, caused by the continued elimination of tourism promotion by the government. The travel and tourism industry is one of the largest in the world and has experienced stable growth in spite of the likely impacts of the COVID-19 pandemic in the future. And yet, the Uganda government has not invested sufficiently in this sector to make transport industry more reliable, timely and affordable for budget tourists. In most cases the transport sector has been left with the private sector making the industry of transportation very expensive and not affordable to the ordinary tourists across the world.

Also, optimization of the TS is anticipated to address the liquidation in the facilities that had subsequently prevented the tourism industry from realizing its potential. More still, continuous training of the existing and potential guides as well as the staff in the Tourism and Hospitality $(\mathrm{TH})$ sector is very crucial. The well-trained staff ensure quality service delivery to travelers in all departments, hence memorable experiences which lead to repeat tourists. Additionally, partnering with the local media and the non-government organizations (NGOs) is also very important. These help in promoting awareness and a positive image about Uganda as the leading tourist destination offering the unbeaten kind of experience to all travelers.

Building the capacity among the previously neglected informal tourism enterprises and emerging entrepreneurs is also recommended. In addition, the provision of information to visitors in all urban centers that keeps them updated on the security situation help in improving their safety and security while in the country. Furthermore, diversification of tourism products aimed at offering good potential for the development is very important. Diverse tourism products encourage various tourism activities, hence attracting repeat visitors.

Finally, an international visitors exit survey be conducted at departure points which should fall under the tourist high season. This is in order to learn what their experiences were and their exposure to UPTA. What best practices in the UPTA are in place? What is/not working in the country for the development of UPTA? This information is essential for all the relevant players in the TS as they work together to guide its development. It is important to note that UPTA are interconnected with the traditional tourist ones. While the suggested recommendations and direction for further research may not be exhaustive, they point to tapping into UPTA for development in the selected municipalities in the country.

\subsection{Limitations of this study}

The three $(7.7 \%)$ selected municipalities that informed this research may not be a good representative of all the municipalities (39) or the many towns (over 156) in the country [45]. Also, the results of this study may not fit directly with a municipality that has metropolitan characteristics such as Kampala Capital City Authority. 


\subsection{Policy implications}

This study links to the 2030 agenda for SDGs Goal 5: Achieving gender equality and empowering all women and girls [46]. Marginalized groups play pivotal roles in the management of unsung tourist activities which is public sector led and private sector driven, implying that the private sector plays a significant role. What is more, marginalized groups possess knowledge about things and have different skills which are handy in the different supply chains of the sector which depends on unskilled manpower. Women's contributions to managing tourism business, however, are seldom acknowledged and their capacity to do so remains unrecognized. This challenge has significant gender dimensions because women and girls, who are increasingly playing an important role in untouched paradise of tourism and hospitality sector, are among the poorest and most disempowered people. One of the reasons for this is the lack of gender-differentiated perspectives, which gap is addressed in this paper.

Therefore, tapping into the fastest growing UPTA for development in selected municipalities in the country addresses the gender inequality and social exclusion. Besides, utilizing the country's natural and cultural heritage endowment by realizing their tourism potential will provide significant benefits to the country. Notwithstanding its early stage of development and contributions, the TS will continue to make dramatic progress as the highest foreign exchange earner. Correspondingly, the sector has a positive spill-over effect on other sectors. The country is now a known international tourism destination of choice, which strongly justifies tapping also into UPTA for the benefits it will provide to marginalized groups in particular and the economy in general. In addition, this paper addresses in particular one of the 8 AU/NEPAD Strategic objective in TS, Objective 4 - Promote research and development [47].

Overall, this study improves the visibility and marketing of UPTA products in the country that are modestly exploited and less commercialized. Moreover, the suggested strategies of strengthening existing and emerging forms of the UPTA will enable the youth, women, service providers and unemployed adults to take part in relevant decision making processes which can influence political power that determines the economy of viable business at a national level. Finally, this paper is in response to the human capital development agendas of National Development Plan II (NDPII) and NDPIII in particular Key Result Area (KRA) 4 - Human capital development in tourism sector, aggressive marketing of tourism products, development of heritage and cultural tourism products in Uganda [48], [49].

\section{ACKNOWLEDGEMENTS}

This publication is one of the project outputs of the staff from the three Universities - KAB, BU and MUST when responding to the call, Window 3 - Skills Development Facility (SDF) by Private Sector Foundation Uganda (PSFU). Title of the submitted Extended Concept Note (ECN): Community Based Education, Research and Service - PLUS (COBERS-PLUS) for the Improvement of Unsung Tourism and Hospitality Potential in Uganda. Project Purpose: A sustainable mechanism of tourism development to benefit the communities in the Eastern and Southwestern Uganda is established through Universities-led innovative skills training and public-private partnerships. Overall Goal: Functional tourism based on distinctive local resources is developed in the Eastern and Southwestern Regions of Uganda. 


\section{REFERENCES}

[1] International Bank for Reconstruction and Development/The World Bank, Tourism: Pacific Possible Background Paper No. 4., 2016.

www.worldbank.org/PacificPossible. Accessed on: 27 Mar. 2020.

[2] Christie, I, Fernandes, E., Messrli, H. \& Twining-Ward, L., Tourism in Africa: Harnessing Tourism for Growth and Improved Livelihoods. The World Bank, 2019. www.worldbank.org/afr/tourism. Accessed on: 10 Jan. 2020.

[3] World Tourism Organization, UNWTO. UNWTO Global Summit on City Tourism, 2011. http://www.unwto.org. Accessed on: 26 Feb. 2020.

[4] NEPAD. The AU/NEPAD African Action Plan 2010-2015: Advancing Regional and Continental Integration in Africa. New Partnership for Africa (NEPAD), 2009. www.nepad.org. Accessed on 21 Mar. 2020.

[5] Priyanto, S.S., Optimizing the Potential Tourist Attraction Culture in the PuppetMuseum Jakarta, 2018. http://Knepublishing.com/index.php/KnE. Accessed on: 16 Apr. 2020.

[6] Ivanovic, M. \& Saayman, M., South Africa calling cultural tourists. African Journal for Physical, Health Education, Recreation and Dance, 3, pp. 138-154, 2013.

[7] The Republic of Kenya, Kenya Tourism Agenda 2018-2022. Ministry of Tourism \& Wildlife, Kenya, 2018. www.tourism.go.ke. Accessed on: 18 Apr. 2020.

[8] International Bank for Reconstruction and Development. Economic Assessment of tourism in Kenya: Standing out from the Herd. The World Bank, 2017. www.worldbank.org. Accessed on: 16 Apr. 2020.

[9] UNWTO. International Tourism Highlights, 2019 ed. www.e-unwto.org.doi. Accessed on: 13 Apr. 2020.

[10] Namukobe, J. et al., Traditional plants used for medicinal purposes by local communities around the Northern sector of Kibale National Park, Uganda. Journal of Ethnopharmacology, 136, pp. 236-245, 2011.

[11] Kamuntu, E. \& Ndiaye, A., Uganda Tourism sector situation Assessment: Tourism Reawakening Report, Technical Document of the World Bank: Kampala, 2012.

[12] Mwaura, F. \& Ssekitoleko, S., Reviewing Uganda's Tourism sector for Economic and Social Upgrading Research Series, No. 91, EPRC, June 2012. www.eprc.or.ug. Accessed on 25 Mar. 2020.

[13] The Republic of Uganda, Bureau of Statistics (UBOS). 2019 Statistical Abstract, 2019, Kampala, Uganda. www.ubos.org. Accessed on: 19 Feb. 2020.

[14] The Republic of Uganda, Uganda Bureau of Statistics (UBOS). 2005 Statistical Abstract, 2005, Kampala, Uganda. www.ubos.org. Accessed on: 19 Feb. 2020.

[15] Cheniki, K. \& Baziz, A., Evaluating the ability of local municipalities to promote strong brand image in Algerian cities. GeoJournal of Tourism and Geosites, 28(1), pp. 21-34, 2020. https://doi.org/10.30892/gtg.28102-440.

[16] Godwin, H. The challenge of over tourism. Responsible Tourism Partnership Working Paper, 4, pp. 1-19, 2017.

[17] Seraphin, H. Sheeran, P. \& Pilato, M., Over-tourism and the fall of Venice as a destination. Journal of Destination Marketing and Management, 9, pp. 374-376, 2018.

[18] The Republic of Uganda, Uganda Bureau of Statistics (UBOS). 2018 Statistical Abstract, 2018, Kampala, Uganda. www.ubos.org. Accessed on: 19 Feb. 2020.

[19] The Republic of Uganda, Bureau of Statistics (UBOS). 2019 Statistical Abstract, 2019, Kampala, Uganda. www.ubos.org. Accessed on: 19 Feb. 2020. 
[20] Uganda Bureau of Statistics (UBOS), The National Labour Force Survey 2016/17 Main Report, Kampala, Uganda, Jun. 2018. www.ubos.org. Accessed on: 19 Feb. 2020.

[21] Jaiyesimi, R., The challenge of implementing the sustainable development goals in Africa. The way forward. African Journal of Reproductive Health, 20(3), pp. 13-18, 2016.

[22] The Republic of Uganda, Uganda Bureau of Statistics (UBOS). The National Labour Force Survey 2016/17 - Main Report, Kampala, Uganda, Jun. 2018. www.ubos.org. Accessed on: 19 Feb. 2020.

[23] Uganda Tourism profile, Uganda Investment Authority, 2002. www.ugandainvest.go.ug. Accessed on: 5 Feb. 2020.

[24] Uganda Tourism profile, Uganda Investment Authority, 2002. www.ugandainvest.go.ug. Accessed on: 5 Feb. 2020.

[25] The Republic of Uganda, Ministry of Tourism, Trade and Industry (2003). Tourism Policy for Uganda, Kampala, Uganda, 2003.

[26] The Republic of Uganda, National Planning Authority (NPA). The National

[26] Development Plan 2011-2015. Ministry of Finance Planning and Economic Development, Uganda. Kampala, Uganda, 2010.

[27] Namukobe, J. et al., Traditional plants used for medicinal purposes by local communities around the Northern sector of Kibale National Park, Uganda. Journal of Ethnopharmacology, 136, pp. 236-245, 2011.

[28] Briggs, P. \& Roberts, A., Uganda: The Bradt Travel Guide, IDC House: England, 2013.

[29] Basudde., Uganda Tourist Industry, New Vision, 1996.

[30] Kiyingi, K., Tourism Industry in Exciting Comeback, New Vision, 1996.

[31] African Wildlife Foundation, Ecotourism Development Project - Bwindi

[31] Impenetrable and Mgahinga Gorilla National Parks, Uganda. A proposal Submitted to USAID Uganda Mission in Collaboration with Uganda National Parks, 1995.

[32] The Republic of Uganda, Migration and Tourism Statistics for Busia, Entebbe and

[32] Malaba, Statistical Bulletin No: MT/1/1995, Vol. 1. Statistical Department, Ministry of Finance and Economic Planning, Kampala, Uganda.

[33] Mahoney, Field and MacGregor. Tourism Marketing, Michigan State University, 1997. http://web1.msue.msu.edu/im/modtd/33700082.html. Accessed on: 8 Jan. 2020.

[34] Lew, A.A., A framework of tourist attraction research. Annals of Tourism Research, 14(4), pp. 553-575, 1987.

[35] Wang, X., Li, X.R., Zhen, F. \& Zhang, J., How smart is your tourist attraction? Measuring tourist preferences of smart tourism attractions via a FCEM-AHP and IPA approach. Tourism Management, 54, pp. 309-332, 2016.

[36] Holden, A., Environment and Tourism, Routledge, 2016.

[37] Campos, A.C., Mendes, J., Valle, P.O.d. \& Scott, N., Co-creation of tourist experiences: A literature review. Current Issues in Tourism, 21(4), pp. 369-400, 2018.

[38] Brundtland, G.H., Brundtland report. Our common future. Comissão Mundial, 4(1), pp. 17-25, 1987.

[39] Valentin, A. \& Spangenberg, J.H., A guide to community sustainability indicators. Environmental Impact Assessment Review, 20(3), pp. 381-392, 2000. 
[40] Deery, M., Jago, L., Harris, C. \& Liburd, J., Work life balance for sustainable tourism development. Collaboration for Sustainable Tourism Development, pp. 151167, 2018.

[41] Hall, C.M., Constructing sustainable tourism development: The 2030 agenda and the managerial ecology of sustainable tourism. Journal of Sustainable Tourism, 27(7), pp. 1044-1060, 2019.

[42] Robinson, G., Methods and Techniques in Human Geography, Wiley: Chichester, 1998.

[43] Rice, S., Sampling in geography. Key Methods in Geography, eds N. Clifford \& J. Valentine, Sage: London, pp. 223-244, 2003.

[44] Andama, E. \& Alezuwo, C., Tourism Potential in the Northern Uganda, A report submitted to Ministry of Tourism, Wildlife and Antiquities, The Republic of Uganda, 2011.

[45] Uganda Bureau of Statistics, 2019 Statistical Abstract, Kampala, Uganda, 2019.

[46] UNDP, Transforming Our World. The 2030 Agenda for Sustainable Development. A/RES/70/1. www.sustainabledevelopment.un.org. Accessed on: 9 Apr., 2020.

[47] NEPAD, Africa Union Commission Agenda 2063. The Africa We Want - A shared Strategic Framework for Inclusive Growth and Sustainable Development: First 10Year Implementation Plan 2014-2023, 2015. www.un.org/en/africa/osaga/pdf/an/ agenda2063-first10yearimplementation.pdf. Accessed on: 8 Apr. 2020.

[48] The Republic of Uganda, National Planning Authority (NPA). NDP II. The National Development Plan 2015-2020. Ministry of Finance Planning and Economic Development, Kampala, Uganda.

[49] The Republic of Uganda, National Planning Authority (NPA). NDP III. The National Development Plan 2021-2025. Ministry of Finance Planning and Economic Development, Kampala, Uganda, 2020. 